\title{
Dietarily-induced changes in voluntary ethanol consumption and ethanol metabolism in the rat
}

\author{
BY LEENA PEKKANEN AND K. ERIKSSON \\ The Research Laboratories of the State Alcohol Monopoly (Alko), \\ Box 350, SF-0010 I Helsinki 10, Finland \\ AND MARJA-LIISA SIHVONEN \\ Department of Chemistry, Helsinki University of Technology, SF-02 150 Espoo 15, Finland
}

(Received 4 July 1977 - Accepted 26 September 1977)

\begin{abstract}
I. The voluntary ethanol consumption, ethanol elimination rate and blood acetaldehyde level after intraperitoneal injection of ethanol were studied in rats receiving diets with highly imbalanced proportions of dietary protein, carbohydrate and fat.

2. The rats, which received the low-protein diet containing 0.05 of the total energy as protein, 0.80 as carbohydrate and 0.15 as fat, drank only approximately half as much ethanol as did the control group, which received 0.30 of its total food energy from protein, 0.55 from carbohydrate and 0.15 from fat. Ethanol elimination rate in the low-protein group was decreased and the blood acetaldehyde level after ethanol injection was markedly increased.

3. On the high-fat diet, which contained 0.30 of the total energy from protein, 0.05 from carbohydrate and 0.65 from fat, the rats drank significantly more ethanol than did the rats on the control diet; their ethanol elimination rate was decreased but their blood acetaldehyde level was not affected.

4. In conclusion, the strong decrease in voluntary ethanol drinking by the low-protein group may have been caused by the increased acetaldehyde accumulation in the blood, but a particularly low blood acetaldehyde level was not one of the factors inducing excessive ethanol drinking in the high-fat group.
\end{abstract}

Ethanol drinking may disturb the nutrient balance because of the energy content of ethanol and because the metabolism of ethanol occurs through the same pathways as proper nutrients. On the other hand ethanol drinking itself seems to be affected by defects in the nutritional state. Deficiencies of specific B-vitamins as well as a diet of generally poor nutritive value have been shown to alter the voluntary ethanol drinking of experimental animals (Brady \& Westerfeld, I947; Beerstecher, Reed, Brown \& Berry, I95I; Mardones, I95I; Brown, 1969; Register, Marsh, Thurston, Fields, Horning, Hardinge \& Sanchez, 1972). In the same way, different proportions of dietary fat, protein and carbohydrate have also been demonstrated to affect the ethanol drinking behaviour of animals (Lester \& Greenberg, 1952; Mirone, 1957; Eriksson, 1969; Brown \& Hutcheson, 1973).

How dietary factors affect voluntary ethanol drinking is not known. However, the amounts of fat, protein and carbohydrate in the diet have been shown to influence the metabolism of ethanol (Berg, Stotz \& Westerfeld, I944; Kerner \& Westerfeld, 1953; Horn \& Manthei, 1965; Pawan, 1968). It is hypothesized that ethanol metabolism may have some role in the regulation of ethanol drinking behaviour, especially through the production of a high acetaldehyde level in the blood after ethanol intake which could cause an aversion to ethanol. However, there are no previous studies in which both the metabolic changes induced by long-term imbalanced proportions of dietary fat, protein and carbohydrate and, at the same time, changes in the voluntary ethanol drinking of experimental animals have been examined. Only in such a study would it be possible to determine if the changes in ethanol metabolism induced by such dietary imbalances are responsible for the alterations in ethanol drinking. 


\section{MATERIALS AND METHODS}

\section{Test animals and diets}

Forty-six male, 3-month-old albino rats of the Sprague-Dawley strain (Anticimex, Sollentuna, Sweden) were used in the study. The animals were individually housed in stainless steel cages with a mesh bottom in a room maintained between $22-24^{\circ}$ and $53-57 \%$ relative humidity. A $\mathrm{I} 2 \mathrm{~h}$ light-I $2 \mathrm{~h}$ dark illumination schedule was used.

In the free-choice situation, as described previously by Eriksson (1969), I·72 M-ethanol $(100 \mathrm{ml} / \mathrm{l})$, tap water and food were freely available for the animals. The food was offered in glass bottles with a hole $60 \mathrm{~mm}$ in diameter through the lid and under that, on top of the food powder, a free-moving aluminium disc perforated all over with $10 \mathrm{~mm}$ holes to prevent wastage of food. The liquids were offered in graduated glass bottles with the mouth about $100 \mathrm{~mm}^{2}$. In previous experiments it was found that the ethanol does not escape from the bottles by evaporation (Eriksson, 1969). The positions of liquid bottles on the front wall of the cage were interchanged once a week to avoid the possible effect of place affinity of rats on their liquid intake. The wastages of liquid and food were found to be insignificant. The water and ethanol consumption were measured at the same time every day and food consumption was measured twice a week.

The compositions of the diets are given in Table I. For calculating the energy content $(\mathrm{kJ} / \mathrm{g})$ of the diets the following coefficients for digestible energy were used: maize-oil fat 37 , carbohydrate in rice starch 17 , protein in rice starch 16 , casein protein 18 , sucrose in the vitamin and salt mixtures I7 (Davidson, Meiklejohn \& Passmore, 1959; Young, 1964; Souci, Fachmann \& Kraut, 1973).

The experimental diets were chosen on the basis of information from earlier studies (Lester \& Greenberg, 1952; Mirone, 1957; Eriksson, 1969; Brown \& Hutcheson, 1973) that the most important factors in the diet for modifying the voluntary ethanol intake of animals would be either high-fat, low-protein or high-carbohydrate concentrations. Three highly imbalanced diets were made so that the energy relation of two of the three components varied while that of the third component remained equal to that of the optimum diet. In the optimum diet 0.30 of the energy content was derived from protein, 0.55 from carbohydrate and 0.15 from fat. The corresponding values for the imbalanced diets were: high-fat, low-carbohydrate diet (HF-LC) $0.30,0.05$ and 0.65 ; high-carbohydrate, low-protein diet (HC-LP) 0.05, 0.80 and 0.15; high-carbohydrate, low-fat diet (HC-LF) 0.30, 0.70 and 0.004.

The vitamin and mineral contents of all the diets, and the protein content in all but the HC-LP diet, were somewhat higher than the recommendations for the rat (Jelinek, I967; Joubert, 1967; Quarterman, 1967; Coates, O’Donoghue, Payne \& Ward, 1969; US National Research Council, 1972). This was necessary because ingestion of ethanol is known to reduce food intake while impairing the intestinal absorption of amino acids (Israel, Salazar \& Rosenmann, 1968) and thiamin (Tomasulo, Kater \& Iber, 1968), increasing the excretion of thiamin, pyridoxine and pantothenic acid (Oura, Konttinen \& Suomalainen, 1963) and increasing hepatic choline uptake (Tuma, Barak \& Sorrell, 1971). Consequently, the amounts of vitamins and minerals were adjusted so as to be proportional to the total energy content of each diet, in order to assure that their intake would be the same. For instance, the HF-LC diet, which has I. 5 times the energy concentration of the optimum diet, had I. 5 times as much salt mixture $/ \mathrm{kg}$; in the instance of the HF-LC diet, this necessitated the use of a more concentrated vitamin mixture to guarantee the same concentration of vitamins relative to the energy content as in the optimum diet (Table I).

For checking the contents of ingredients and for controlling the mixing of the diets, chemical analyses of trace elements and amino acids were made for one sample of each diet. The amino acid contents, except cysteine and tryptophan, were determined using an auto- 


\section{Table I. Composition $(\mathrm{g} / \mathrm{kg})$ of the experimental diets}

\begin{tabular}{|c|c|c|c|c|}
\hline \multirow[b]{2}{*}{ Ingredients } & \multicolumn{4}{|c|}{ Diet } \\
\hline & Optimum & $\begin{array}{l}\text { High-fat, low- } \\
\text { carbohydrate }\end{array}$ & $\begin{array}{l}\text { High-carbo- } \\
\text { hydrate, low- } \\
\text { protein }\end{array}$ & $\begin{array}{c}\text { High-carbo- } \\
\text { hydrate, low- } \\
\text { fat }\end{array}$ \\
\hline $\begin{array}{l}\text { Casein (30 mesh)* } \\
\text { Rice starch* }\end{array}$ & $\begin{array}{l}295 \\
55 \mathrm{I}\end{array}$ & $\begin{array}{l}467 \\
61\end{array}$ & $\begin{array}{l}46 \\
801\end{array}$ & $\begin{array}{l}263 \\
636\end{array}$ \\
\hline Maize oil* & 53 & $37 \mathrm{I}$ & 52 & 0 \\
\hline Fat-soluble vitamin mixture & it & if & $1 \dagger$ & $1 \dagger$ \\
\hline $\begin{array}{l}\text { Water-soluble vitamin mixture } \\
\text { Salt mixture }\end{array}$ & $40 \S$ & Ioll & $40 \$$ & $40 \$$ \\
\hline Energy content $(\mathrm{MJ} / \mathrm{kg})$ & $14 \cdot 2$ & $22 \cdot 3$ & $13 \cdot 8$ & $12 \cdot 8$ \\
\hline Energy derived from & & & & \\
\hline Protein & 0.30 & 0.30 & 0.05 & 0.30 \\
\hline Carbohydrate & 0.55 & 0.05 & 0.80 & 0.70 \\
\hline Fat & 0.15 & 0.65 & 0.15 & $<0.005$ \\
\hline
\end{tabular}

* Yliopiston apteekki, Helsinki, Finland.

$\dagger$ Composed of: $3.0 \mathrm{mg}$ retinyl palmitate (Hoffmann \& La Roche, Basle, Switzerland), $0.5 \mathrm{mg}$ ergocalciferol (Fluka AG, Buchs, Switzerland), I mg menaquinone (Fluka AG), $208 \mathrm{mg}$ DL- $\alpha$-tocopherol (Merck, Darmstadt, Germany) and $788 \mathrm{mg}$ maize oil.

¥ Composed of: $4.5 \mathrm{mg}$ retinyl palmitate, $0.08 \mathrm{mg}$ ergocalciferol, $1.5 \mathrm{mg}$ menaquinone, $\alpha$-tocopherol was not included because the vitamin E content of maize oil was $0.84 \mathrm{~g} / \mathrm{kg}$ (Souci, Fachmann \& Kraut, 1973) and $994 \mathrm{mg}$ maize oil.

$\$$ Composed of : $0.5 \mathrm{mg}$ biotin chloride (Nutritional and Biochemical Corporation, Cleveland, Ohio), $2 \mathrm{~g}$ choline chloride (Merck), I mg folic acid (Fluka AG), $20 \mathrm{mg}$ calcium pantothenate (Hoffmann \& LaRoche), $500 \mathrm{mg}$ myo-inositol, (Fluka AG), $30 \mathrm{mg}$ nicotinamide (Hoffmann \& LaRoche), $200 \mathrm{mg} p$-aminobenzoic acid (Merck), $16 \mathrm{mg}$ riboflavin (Merck), $8 \mathrm{mg}$ thiamin hydrochloride (Hoffmann \& LaRoche), Io mg pyridoxine hydrochloride (Fluka AG), $0.02 \mathrm{mg}$ cyanocobalamin (Merck), $50 \mathrm{mg}$ ascorbic acid (Merck), $37 \mathrm{~g}$ sucrose (Suomen Sokeri, Helsinki, Finland).

II Composed of: $0.75 \mathrm{mg}$ biotin chloride, $3 \mathrm{~g}$ choline chloride, $1.5 \mathrm{mg}$ folic acid, $30 \mathrm{mg}$ calcium pantothenate, $750 \mathrm{mg}$ myo-inositol, $45 \mathrm{mg}$ nicotinamide, $300 \mathrm{mg}$-aminobenzoic acid, $24 \mathrm{mg}$ riboflavin, $12 \mathrm{mg}$ thiamin hydrochloride, I $5 \mathrm{mg}$ pyridoxine hydrochloride, $0.03 \mathrm{mg}$ cyanocobalamin, $0.75 \mathrm{mg}$ ascorbic acid, $5 \cdot 7 \mathrm{~g}$ sucrose.

If Composed of: $525 \mathrm{mg}$ ferricitrate (Merck), $157 \mathrm{mg} \mathrm{Cu} \mathrm{SO}_{4} \cdot 5 \mathrm{H}_{2} \mathrm{O}$ (Merck), I $9 \mathrm{mg} \mathrm{MnSO}_{4} \cdot \mathrm{H}_{2} \mathrm{O}$ (Merck), $38 \mathrm{mg} \mathrm{ZnCO}$ (Baker, Phillipsburg), $6.54 \mathrm{~g} \mathrm{MgSO}_{4} \cdot 7 \mathrm{H}_{2} \mathrm{O}$ (Merck), $0.26 \mathrm{mg} \mathrm{KI}$ (Merck), $17.3 \mathrm{~g}$ $\mathrm{KH}_{2} \mathrm{PO}_{4}$ (Baker), $17 \cdot 5 \mathrm{~g}$ calcium lactate (Yliopiston apteekki), I 2.7 $\mathrm{g} \mathrm{NaCl}$ (Merck), $5 \cdot \mathrm{I} \mathrm{g}$ sucrose (Suomen Sokeri).

** Composed of : $788 \mathrm{mg}$ ferricitrate, $236 \mathrm{mg} \mathrm{Cu} \mathrm{SO}_{4} \cdot 5 \mathrm{H}_{2} \mathrm{O}, 179 \mathrm{mg} \mathrm{MnSO}{ }_{4} \cdot \mathrm{H}_{2} \mathrm{O}, 57 \mathrm{mg} \mathrm{ZnCO}, 9.8 \mathrm{Ig}$ $\mathrm{MgSO}_{4} \cdot 7 \mathrm{H}_{2} \mathrm{O}, 0.39 \mathrm{mg} \mathrm{KI}, 26 \mathrm{~g} \mathrm{KH}_{2} \mathrm{PO}_{4}, 26 \cdot 3 \mathrm{~g}$ calcium lactate, $19 \mathrm{~g} \mathrm{NaCl}, 7 \cdot 7 \mathrm{~g}$ sucrose.

if Composed as 1 except $5 \cdot 1 \mathrm{~g} \mathrm{NaH} \mathrm{PO}_{4} . \mathrm{H}_{2} \mathrm{O}$ (Merck) was added instead of sucrose in order to compensate for the phosphorus in casein ( $10 \mathrm{~g} / \mathrm{kg}$; US National Research Council, 1972). All ingredients for the salt mixtures were of analytical quality.

matic amino acid analyser (Jeol, G AH, Japan Electron Optics Laboratory Ltd, Tokyo, Japan) after hydrolysation with $6 \mathrm{M}$-hydrochloric acid at $136^{\circ}$ and $2 \cdot 2$ atm for $3 \mathrm{~h}$. Cysteine was determined as cysteinic acid according to Schramm, Moore \& Bigwood (1954). Tryptophan was analysed spectrometrically according to the method of Graham, Smith, Hier \& Klein (1947).

The analyses of the trace elements were made with a spark source mass spectrometer with electrical detection (double-focusing mass spectrometer MS 702 with radio amplifier and autospark unit; Associated Electrical Industries, Manchester). Heikonen (1973) has described the ashing and the recovery studies in detail; the analysis procedure was performed as described previously (Bingham \& Elliot, I97I; Sihvonen, 1972). The electrodes were made from a mixture of $100 \mathrm{mg}$ diet ash and $100 \mathrm{mg}$ pure graphite (Ringsdorf RWA, Bonn-Bad Godesberg, Germany) by the polythene-slug technique (Sihvonen, 1972). The standard 
Table 2. Concentrations of amino acid $(\mathrm{g} / \mathrm{MJ})$ and trace elements $(\mathrm{mg} / \mathrm{MJ})$ of the experimental diets*

(Values have been calculated with an automatic amino acid analyser for amino acids and with a mass spectrometer for trace elements)

Amino acids

Aspartic acid

Threonine

Serine

Glutamic acid

Proline

Glycine

Alanine

Valine

Methionine

Isoleucine

Leucine

Tyrosine

Phenylalanine

Lysine

Histidine

Arginine

Cysteine

Tryptophan

Nitrogen

Trace elements

Molybdenum

Bromine

Zine

Copper

Nickel

Cobalt

Iron

Manganese

Chromium

Tin

Barium

Vanadium

\begin{tabular}{|c|c|c|c|}
\hline \multicolumn{4}{|c|}{ Diet $\dagger$} \\
\hline Optimum & $\mathrm{HF}-\mathrm{LC}$ & HC-LP & $\mathrm{HC}-\mathrm{LF}$ \\
\hline I & I & 0.3 & I \\
\hline I & I & 0.2 & I \\
\hline $\mathbf{I}$ & $\mathbf{I}$ & 0.2 & I \\
\hline 5 & 4 & 0.9 & 4 \\
\hline 2 & 2 & 0.4 & 2 \\
\hline 0.4 & 0.4 & 0.08 & 0.4 \\
\hline 0.6 & 0.6 & 0.1 & 0.6 \\
\hline I & I & 0.3 & I \\
\hline 0.6 & 0.6 & $0 \cdot 1$ & 0.6 \\
\hline I & I & 0.2 & I \\
\hline 2 & 2 & 0.4 & 2 \\
\hline I & I & 0.2 & I \\
\hline I & $\mathbf{I}$ & 0.2 & $\mathbf{I}$ \\
\hline I & I & 0.3 & I \\
\hline 0.6 & 0.8 & 0.1 & 0.7 \\
\hline 0.6 & 0.6 & 0.1 & 0.6 \\
\hline 0.07 & 0.06 & 0.02 & 0.08 \\
\hline 0.3 & 0.2 & 0.01 & 0.2 \\
\hline 3 & 3 & 0.6 & 3 \\
\hline 0.003 & 0.004 & 0.005 & 0.006 \\
\hline 0.3 & 0.2 & 0.04 & 0.05 \\
\hline 4 & 4 & 3 & 5 \\
\hline 4 & 4 & 4 & 6 \\
\hline 0.4 & 0.2 & 0.2 & 0.2 \\
\hline 0.0002 & 0.005 & 0.0005 & 0.002 \\
\hline 6 & 6 & 6 & 7 \\
\hline 3 & 2 & 2 & 3 \\
\hline 0.01 & 0.02 & 0.02 & 0.01 \\
\hline- & - & 0.006 & 0.003 \\
\hline 0.02 & 0.02 & 0.02 & 0.04 \\
\hline 0.008 & 0.01 & 0.01 & 0.007 \\
\hline
\end{tabular}

* For details of composition see Table $\mathbf{I}$.

$\dagger$ HF-LC: high-fat, low-carbohydrate; HC-LP: high-carbohydrate, low-protein; HC-LF: high-carbohydrate, low-fat.

samples were made by adding the elements (Spex Mix, Metuchen, New Jersey, USA) to graphite and mixing it with a synthetic, spectrally-pure matrix. The accuracy of the method is better than $\pm 20 \%$ (Sihvonen, 1972; Yliruokanen, 1975).

As qualitative confirmations of the results obtained by the mass spectrometric method, an $\mathrm{X}$-ray fluorescence analysis was made for the following elements : zinc, copper, nickel, iron, manganese, and chromium. The analyses were made with a semi-automatic X-ray spectrometer (PW I220/00, Philips, Eindhoven, Netherlands) equipped with an X-ray tube $(100 \mathrm{kV} / 2 \mathrm{~kW}$ ), a tungsten anode (PW 2I64/00), a lithium fluoride analysing crystal (2d $0.4028 \mathrm{~nm}$ ), a flow counter and a scintillation counter. The sampling and the standards were prepared as described previously (Erämetsä, Lounamaa \& Haukka, I969). The error of the method including all systematic and random errors is $\leqslant 10 \%$ (Erämetsä \& Haukka, 1970; Heikonen, 1973).

Table 2 shows the amounts (per MJ) of amino acids and trace elements. Comparing the 
dietary compositions to some recommended values for the laboratory rat showed that all the diets should have been nutritionally quite adequate except for a deficiency of some essential amino acids in the HC-LP diet (US National Research Council, 1972). It provided approximately the following proportions of those essential amino acids normally needed for growth: tryptophan 0.125 , methionine + cystine 0.250 , lysine and histidine 0.330 , valine, isoleucine and threonine 0.500 , and leucine and phenylalanine + tyrosine 0.660 . Comparing the intake of these elements from the tap-water, which were the most abundant in the tap-water on the basis of the mineral analysis by The Helsinki City Waterworks, to the intake of these elements from the food shows that the rats have received from the tap-water only 0.00 I of their daily zinc intake, 0.002 of their daily iron intake and 0.01 of their daily manganese intake.

The diets were made once a week by mixing ingredients carefully with a Hobart PF-60I mixer (Ivry-s-Seine, France). They were stored at $4^{\circ}$.

\section{Measurement of ethanol elimination rate and blood acetaldehyde}

The ethanol elimination rate and blood acetaldehyde level were estimated from tail-blood samples taken $30,90,150$ and 210 min after an intraperitoneal injection of $1.5 \mathrm{~g}$ ethanol $/ \mathrm{kg}$ body-weight as a $2 \cdot 17 \mathrm{M}$-ethanol solution in saline ( $100 \mathrm{~g}$ ethanol $/ 1 ; 9 \mathrm{~g}$ sodium chloride/l). Blood ethanol and acetaldehyde were determined by gas-liquid chromatography and the ethanol elimination rates were calculated as described previously (Koivula \& Lindros, 1975).

\section{Experimental procedure}

All animals received the optimum diet and tap-water $a d$ lib. during a habituation period of 4 weeks in order to guarantee initially a similar nutritional state. Then the basic ethanol elimination rate and the blood acetaldehyde level after acute ethanol injection were measured. The rats were divided into four groups matched with respect to body-weight, ethanol elimination rate and blood acetaldehyde level, and were given one of four different test diets: optimum ( $n$ I6), HF-LC ( $n$ I0), HC-LP ( $n$ I0) and HC-LF ( $n$ I0). After this 4-week diet period, when each group had received its diet and tap-water ad lib. there was a 4-week ethanol free-choice period, when each group received its diet, tap-water and I.72 M-ethanol (I00 ml/l) ad lib. The optimum-diet group was divided in two groups: optimum-diet group A $(n+10)$ received an ethanol choice while optimum-diet group B $(n 6)$ was not offered ethanol in order to control the influence of ethanol choice on ethanol metabolism, growth rate and consumption of energy and fluids. The ethanol elimination rates and blood acetaldehyde levels were measured again after the first and third weeks of the diet period and after the first and fourth weeks of the ethanol free-choice period.

During the study the fluid and food consumption and food wastages were measured every day between $15-16 \mathrm{~h}$. Fresh food and fluid were provided every other day. The rats were weighed once a week.

\section{RESULTS}

\section{Body-weight and energy intake}

The total energy intake of the rats, on a body-weight basis, showed a normal tendency to decrease slightly on all diets as the growth rate slowed down during aging (Table 3 ). The nutritional adequacy of all the diets except the HC-LP diet was supported by the normal growth rates observed with them. The HC-LP diet caused a decrease in body-weight (Table 3), such that both at the end of the diet period and of the ethanol free-choice period, the HC-LP rats were significantly lighter than the optimum-diet group A animals $(P<0.001)$. The HC-LP diet was apparently well accepted by the rats and there was no 


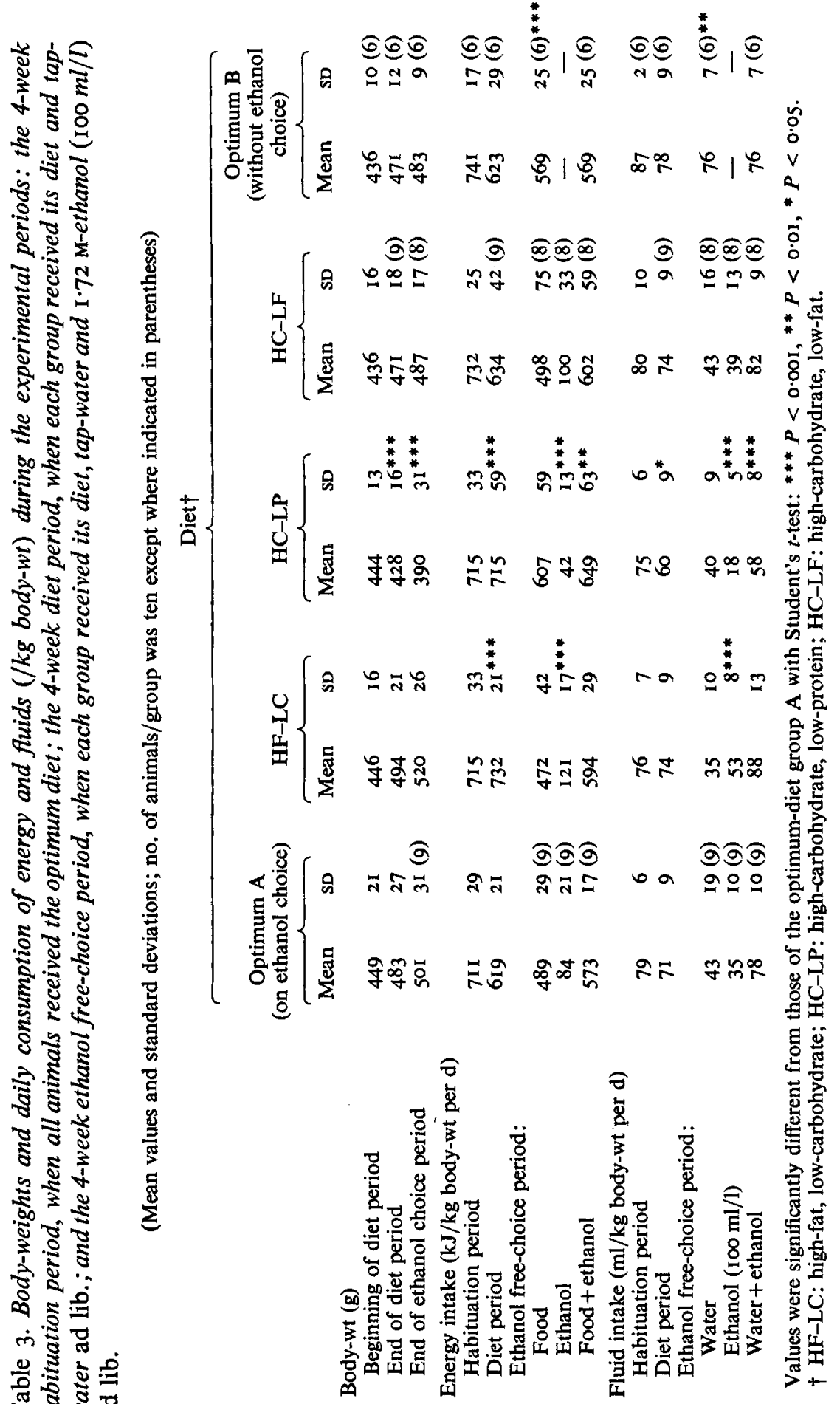


Table 4. Dietarily-induced changes in free-choice consumption of ethanol in different dietary groups during the 4-week ethanol choice period of the experiment $\dagger$

(Mean values and standard deviations)

\begin{tabular}{|c|c|c|c|c|c|c|c|}
\hline \multirow{3}{*}{ Diet } & \multirow{3}{*}{$\begin{array}{l}\text { No. of } \\
\text { animals/ } \\
\text { group }\end{array}$} & \multicolumn{6}{|c|}{ Ethanol intake } \\
\hline & & \multicolumn{2}{|c|}{$\begin{array}{c}\text { Energy from } \\
\text { ethanol (\% total) }\end{array}$} & \multicolumn{2}{|c|}{$\begin{array}{l}\text { I·72 M-ethanol } \\
\text { intake (\% total } \\
\text { fluid intake) }\end{array}$} & \multicolumn{2}{|c|}{$\begin{array}{l}\text { Absolute ethanol } \\
\text { (g/kg body-wt } \\
\text { per d) }\end{array}$} \\
\hline & & Mean & SD & Mean & SD & Mean & SD \\
\hline Optimum A & 9 & 14.3 & $4 \cdot \mathrm{I}$ & 45.4 & 13.4 & $2 \cdot 8$ & 0.8 \\
\hline $\begin{array}{l}\text { HF-LC } \neq \\
\text { HC-LP }\end{array}$ & $\begin{array}{l}10 \\
10\end{array}$ & $\begin{array}{r}20 \cdot 8 \\
6 \cdot 6\end{array}$ & $3 \cdot 9^{* *}$ & $60 \cdot 0$ & $7 \cdot 5^{* *}$ & $4 \cdot 2$ & $\begin{array}{l}0.6^{* * *} \\
0.4^{* * *}\end{array}$ \\
\hline HC-LF $\ddagger$ & 8 & $17 \cdot 2$ & 6.6 & 48.6 & $\begin{array}{l}9 \cdot 7 \\
16 \cdot 6\end{array}$ & $\begin{array}{l}1.4 \\
3.4\end{array}$ & $\begin{array}{l}4 \\
1 \cdot 2\end{array}$ \\
\hline
\end{tabular}

Values were significantly different from those of the optimum-diet group A with Student's $t$-test: ${ }^{* * *} P<0.001, * * P<0.01, * P<0.05$.

+ For details, see p. 107.

$\ddagger$ HF-LC: high-fat, low-carbohydrate; HC-LP: high-carbohydrate, low-protein; HC-LF: high-carbohydrate, low-fat.

self-inflicted starvation and energy deficiency. Their energy consumption on a body-weight basis was considerably higher than in the other diet groups: significantly higher than that of the optimum-diet group A both during the diet period $(P<0.001)$ and during the ethanol free-choice period $(P<0.0 \mathrm{I})$. The weight decrease was, therefore, apparently caused by protein deficiency and by lowered utilization of the low-protein diet.

The rats on the HF-LC diet did not immediately compensate for the higher energy content of their food. Consequently, during the diet period their energy consumption was significantly greater than that of the optimum-diet group A $(P<0.00 \mathrm{I})$; during the ethanol free-choice period it returned to being similar to that of the optimum-diet group A. Total energy consumption of the group on the HC-LF diet did not differ from that of the optimumdiet group A.

Voluntary ethanol consumption during the ethanol free-choice period did not affect the growth rate or the total energy intake of the rats on the optimum diet as shown by comparison of the optimum-diet group A on ethanol free-choice with the optimum-diet group B without ethanol choice (Table 3). The rats compensated for their intake of energy from ethanol by decreasing their consumption of food energy. The total fluid requirement was not changed markedly by any of the diets except the HC-LP diet, where there was a typical lowered fluid requirement on the low-protein diet (Table 3).

\section{Ethanol consumption}

The mean daily ethanol intake of the rats during the 4-week ethanol free-choice period is presented in Table 4. The voluntary ethanol consumption of the group on the HF-LC diet was significantly higher than that of the optimum-diet group A regardless of whether it was expressed as a percentage of the total energy intake obtained from ethanol $(P<0.01)$, as the percentage of the intake of $\mathrm{I} \cdot 72 \mathrm{M}$-ethanol solution $(P<0.0 \mathrm{I})$ or as the amount of absolute ethanol $(\mathrm{g})$ per body-weight $(P<0.00 \mathrm{I})$. The ethanol consumption of the group on the HC-LP diet was on the other hand significantly lower than that of the optimum-diet group $A$ when expressed as the percentage of ethanol energy intake $(P<0.001)$ or as $\mathrm{g}$ absolute ethanol $(P<0.00 \mathrm{I})$. The HC-LF diet did not have a significant influence on the voluntary ethanol intake. 


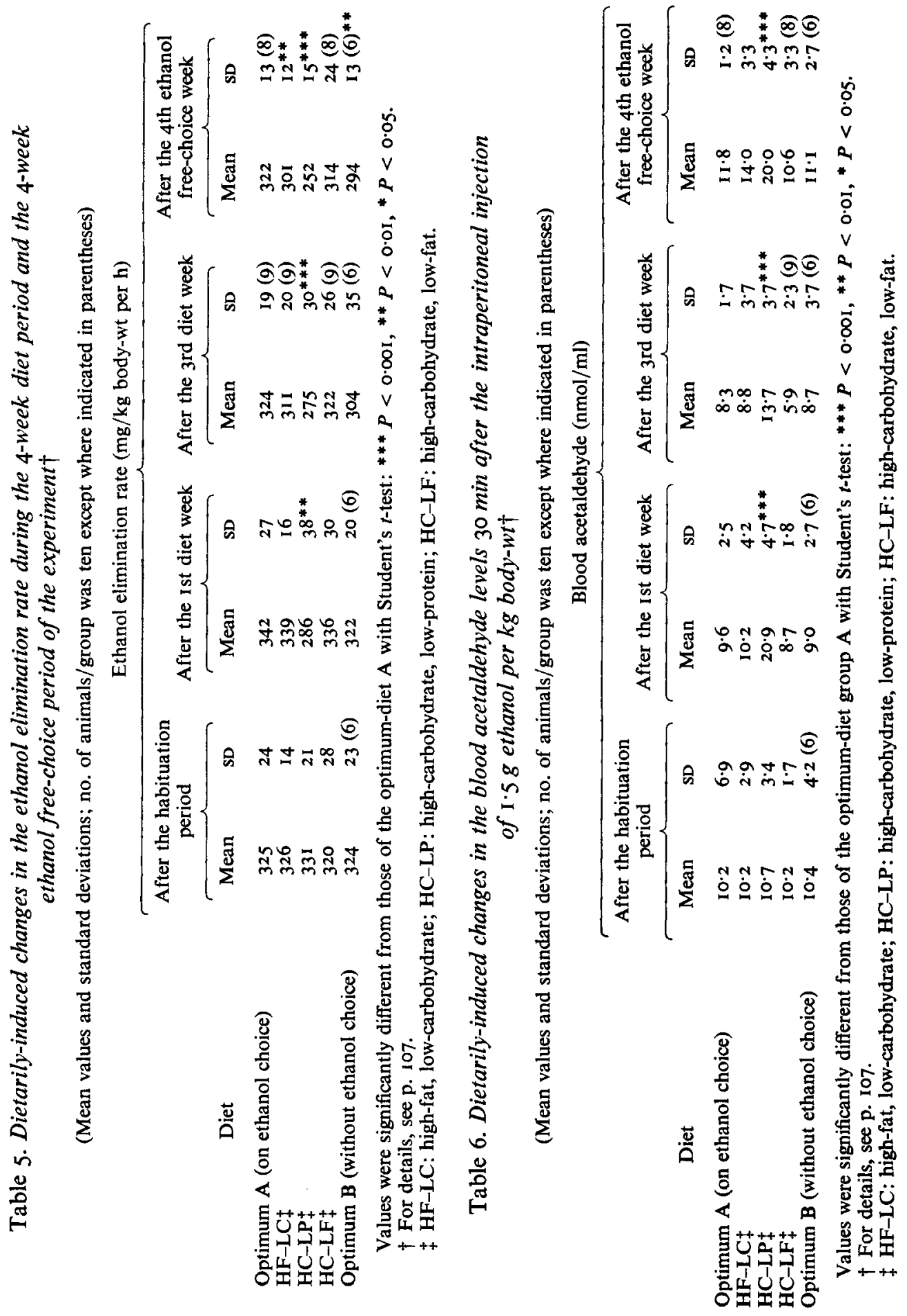




\section{Ethanol elimination rate and blood acetaldehyde}

Table 5 shows the ethanol elimination rates and Table 6 blood acetaldehyde levels 30 min after the ethanol injection. The ethanol elimination rate of the group on the HC-LP diet after only I week on its low-protein diet was significantly lower than that of the optimumdiet group A (Table 5; $P<0.0 \mathrm{I}$ ) and continued to decrease to the end of the study $(P<0.001)$. Similarly, their blood acetaldehyde level $30 \mathrm{~min}$ after the ethanol injection was significantly higher after only I week on the diet than that of the optimum-diet group A (Table 6;P<0.001). The ethanol elimination rate was also lowered in the group on the HF-LC diet; the decrease was statistically significant at the end of the ethanol free-choice period, when the group had received its high-fat diet for 8 weeks $(P<0.0 \mathrm{I})$. However, the blood acetaldehyde of the group on the HF-LC diet was not affected. The HC-LF diet had no influence on the ethanol elimination rate or on the acetaldehyde level in the blood.

A significant difference was found between ethanol elimination rate of the optimum-diet group A and the optimum-diet group B (Table 5; $P<0.01$ ). Actually, the elimination rates of both groups showed a decrease during the study, possibly because of aging. The decrease by the optimum-diet group A was, however, smaller, apparently as a result of drinking approximately $2.8 \mathrm{~g}$ ethanol $/ \mathrm{kg}$ per $\mathrm{d}$.

\section{DISCUSSION}

The results showed clearly that the free-choice consumption of ethanol increased markedly in rats given the HF-LC diet and decreased in rats given the HC-LP diet. These findings are in agreement with previous studies by Lester \& Greenberg (1952) and Brown \& Hutcheson (1973) but are not in good agreement with the results of some other investigators. Mirone (1957) found that a high-fat, low-protein diet decreased the ethanol intake of mice, a highprotein, low-carbohydrate diet increased it, while both a high-carbohydrate, low-protein diet and a protein-free diet were ineffective. Eriksson (1969) showed that a high-fat diet, which was totally free of carbohydrates decreased the ethanol intake of rats. One possible reason for the contradictions between these results and our results, at least with the high-fat diets, could be a difference in intakes of some vitamins between various experimental groups. If the vitamin contents of the diets are the same on a weight basis but not relative to energy density, the animals, which tend to consume a constant amount of energy will receive a lower level of vitamins on a high-energy diet than on a low-energy diet. Moreover, it is known that chronic ethanol intake increases excretion and disturbs intestinal absorption of some vitamins (Somogyi \& Kopp, 1976). Since nutritional deficiencies of vitamins, especially those of B-vitamins, have been shown to alter the voluntary ethanol consumption of experimental animals (Brady \& Westerfeld, I947; Beerstecher et al. 195I ; Mardones, I95I ; Brown, I969), it is possible that vitamin deficiencies could also arise in dietarily-imbalanced situations that could influence ethanol drinking behaviour. For instance, both a high-fat diet and ethanol ingestion increase the requirement of the rat for choline (Lucas \& Ridout, 1967; Tuma et al. 1971). Hillbom (1967) has shown that on a high-fat, low-protein diet, the deficiency of choline lowered the voluntary ethanol intake of rats. According to this hypothesis, the rats on the HF-LC diet in our study would not be restricted from drinking relatively large amounts of ethanol because the choline content of the diet would be sufficient to prevent deficiency.

The biochemical basis by which variations in the amounts of dietary fat, carbohydrate and protein alter ethanol drinking behaviour has been studied very little. The ethanol elimination rate in the present study was decreased both in the group on the HF-LC diet, which drank most ethanol, and in the group on the HC-LP diet, which drank least ethanol. Thus changes in the ethanol elimination rate do not explain the ethanol drinking behaviour, which is in 
agreement with earlier findings with strains of animals differing in their preference for ethanol (Sheppard, Albersheim \& McClearn, 1970; Forsander \& Eriksson, 1972).

Recently two theories about mechanisms regulating voluntary ethanol consumption have been emphasized: one is based on the amount of brain monoamines acting in the transfer of nervous impulse (Ahtee \& Eriksson, 1973, 1975), the other is based on the amount of aversive acetaldehyde in the blood formed during oxidation of ethanol. In the present study we also measured the amount of 5-hydroxytryptamine, dopamine and noradrenaline in the brain. We found, however, no clear relationship between the amounts of these amines in the whole-brain homogenate and the differences in voluntary ethanol drinking of the rats. The results have been published in more detail elsewhere (Eriksson, Pekkanen, Forsander \& Ahtee, 1975).

The hypothesis that the extent of acetaldehyde accumulation in the blood after ethanol intake is one of the mechanisms that regulates ethanol drinking behaviour of experimental animals by causing an aversion to ethanol, is based upon the findings in the heavy-drinking and non-drinking animal strains. The blood acetaldehyde level has been found to be higher after an ethanol injection in non-drinking animals than in heavy-drinking animals (Sheppard et al. 1970; Eriksson, 1973). When the blood acetaldehyde level is increased experimentally by inhibiting aldehyde dehydrogenase (EC I.2.I.3) with Antabus ${ }^{\circledR}$ (disulfiram) or a commercial diet containing cyanamide rats reduce their voluntary ethanol consumption (Schlesinger, Kakihana \& Bennet, 1966; Marchner \& Tottmar, 1976). Consistent with this hypothesis in the present study the group on the HC-LP diet, which drank least ethanol, had a higher blood acetaldehyde level and lower aldehyde dehydrogenase activity than the optimum-diet group (Lindros, Pekkanen \& Koivula, 1977). It should be noted that in this group, both the alcohol dehydrogenase activity ( $E C$ I. I I . I) Lindros et al. 1977) and the ethanol elimination rate were decreased. Since the acetaldehyde levels were increased the protein deficiency must have been more effective in depressing the enzyme systems in acetaldehyde elimination than in ethanol elimination. Contrary to the acetaldehyde hypothesis we did not find a decrease in the blood acetaldehyde level of the group on the HF-LC diet, which drank the most ethanol. The present study, therefore, suggests that high amounts of acetaldehyde accumulating in the blood during ethanol oxidation may depress the voluntary ethanol consumption of rats, but particularly low blood acetaldehyde levels are not necessary for ethanol drinking to be increased.

\section{REFERENCES}

Ahtee, L. \& Eriksson, K. (1973). Ann. N.Y. Acad. Sci. 215, I 26.

Ahtee, L. \& Eriksson, K. (1975). Acta physiol. scand. 93, 563.

Beerstecher, E., Reed, J. G., Brown, W. D. \& Berry, L. J. (1951). Univ. Tex. Publs, no. 5109, p. 115.

Berg, R. L., Stotz, E. \& Westerfeld, W. W. (1944). J. biol. Chem. 152, 5 I.

Bingham, R. A. \& Elliot, R. M. (1971). Analyt. Chem. 43, 43.

Brady, R. A. \& Westerfeld, W. W. (1947). Q. Jl Stud. Alc. 7, 499.

Brown, R. V. (I969). Q. Jl Stud. Alc. 30, 592.

Brown, R. V. \& Hutcheson, D. P. (1973). Q. Jl Stud. Alc. 34, 758.

Coates, M. E., O'Donoghue, P. N., Payne, P. R. \& Ward, R. J. (1969). Laboratory Animal Handbook. 2. Dietary Standards for Laboratory Rats and Mice. London: Laboratory Animals Ltd.

Davidson, S., Meiklejohn, A. P. \& Passmore, R. (1959). Human Nutrition and Dietetics, p. 14. Edinburgh and London: Livingstone Ltd.

Erämetsă, O. \& Haukka, M. (1970). Suom. Kemistilehti B 43, I 89.

Erämetsä, O., Lounamaa, K. J. \& Haukka, M. (1969). Suom. Kemistilehti B 42, 363.

Eriksson, C. J. P. (1973). Biochem. Pharmac. 22, 2283.

Eriksson, K. (1969). Ann. Zool. fenn. 6, 227.

Eriksson, K., Pekkanen, L., Forsander, O. \& Ahtee, L. (1975). Finn. Found. Alc. Stud. 24, I 5.

Forsander, O. \& Eriksson, C. J. P. (1972). Finn. Found, Alc. Stud. $20,43$.

Graham, C. E., Smith, E. P. .Hier, S. W. \& Klein, P. (I 947). J. biol. Chem. r68, 7 I I. 
Heikonen, M. (1973). X-ray fluorescence spectroscopic methodology in trace element analyses: a critique and an application to the assessment of the trace elements status of cows given protein-free feed. Doctoral Thesis, Helsinki University of Technology, Finland.

Hillbom, M. (1967). Japan. J. Stud. Alc. 2, I I I.

Horn, R. S. \& Manthei, R. W. (1965). J. Pharmac. exp. Ther. 147, 385.

Israel, Y., Salazar, I. \& Rosenmann, E. (1968). J. Nutr. 96, 499.

Jelinek, V. (1967). In Husbandry of Laboratory Animals, p. 97 [M. L. Conalty, editor]. New York and London: Academic Press.

Joubert, C. J. (1967). In Husbandry of Laboratory Animals, p. I 33 [M. L. Conalty, editor]. New York and London: Academic Press.

Kerner, E. \& Westerfeld, W. W. (1953). Proc. Soc. exp. Biol. Med. 83, 530.

Koivula, T. \& Lindros, K. (1975). Biochem. Pharmac. 24, 1937.

Lester, D. \& Greenberg, L. A. (1952). Q. Il Stud. Alc. 13, 553.

Lindros, K., Pekkanen, L. \& Koivula, T. (1977). Acta pharmac. tox. 40, I 34.

Lucas, C. C. \& Ridout, J. H. (1967). Prog. Chem. Fats ıo, 37, 98.

Marchner, H. \& Tottmar, O. (1976). Acta pharmac. tox. 39, 331.

Mardones, J. (1951). Q. Jl Stud. Alc. 12, 563.

Mirone, L. (1957). Q. Jl Stud. Alc. 18, 552.

National Research Council (1972). Nutrient Requirements of Domestic Animals, no. 10, Nutrient Requirements of Laboratory Animals. Washington: National Academy of Sciences.

Oura, E., Konttinen, K. \& Suomalainen, H. (1963). Acta physiol. scand. 59, suppl. 2 I 3, I 19.

Pawan, G. L. S. (I 968). Proc. Nutr. Soc. 27, 58 A.

Quarterman, J. (1967). In Husbandry of Laboratory Animals, p. 97 [M. L. Conalty, editor]. New York and London: Academic Press.

Register, U. D., Marsh, S. R., Thurston, C. T., Fields, B. J., Horning, M. C., Hardinge, M. G. \& Sanchez, A. (1972). J. Am. diet. Ass. 6r, 159.

Schlesinger, K., Kakihana, R. \& Bennet, E. L. (1966). Psychosom. Med. 38, 514.

Schramm, E., Moore, S. \& Bigwood, E. J. (1954). Biochem. J. 57, 33.

Sheppard, J. R., Albersheim, P. \& McClearn, G. (1970). J. biol. Chem. 245, 2876.

Sihvonen, M.-L. (1972). Annls Acad. Sci. fenn., ser. A. II, r68, 62.

Somogyi, J. C. \& Kopp, P. M. (1976). Biblthca 'Nutr. Dieta' 24, 17.

Souci, S. W., Fachmann, W. \& Kraut, H. (1973). Die Zusammensetzung der Lebensmittel, Nährwerttabellen, I-II. Stuttgart: Wissenschaftliche Verlagsgesellschaft MBH.

Tomasulo, P. A., Kater, R. M. H. \& Iber F. L. (I968). Am. J. Nutr. 21, I 34 I.

Tuma, D. J., Barak, A. J. \& Sorrell, M. F. (1971). Nutr. Rep. int. 4, 165.

Yliruokanen, I. (1975). Annls Acad. Sci. fenn., ser. A. II, r76, 28.

Young, E. G. (1964). In Nutrition, vol, 2, p. 299 [G. H. Beaton and E. W. McHenry, editors]. New York and London: Academic Press. 